\title{
Adaptability parameters of the winter durum wheat varieties of various ecology in the Rostov region
}

\author{
Tatiyana Makarova ${ }^{1,}{ }^{*}$, Nina Samofalova ${ }^{1}$, Nina Ilichkina $^{1}$, Olga Dubinina ${ }^{1}$, Aleksey Popov ${ }^{1}$, \\ Oksana Kostylenko ${ }^{1}$ \\ ${ }^{1}$ FSBSI “Agricultural Research Center “Donskoy”, 3, Nauchny Gorodok Str., 347740, Zernograd, \\ Rostov region, Russia
}

\begin{abstract}
There have been generalized the study results of the parameters of ecological adaptability of winter durum wheat and there have been identified the most adaptive varieties of different ecology under unstable climatic conditions of the Rostov region. There was conducted the analysis of 34 varieties of domestic and foreign breeding, which have been recommended for cultivation in different climatic zones. During the current study there have been identified the groups of winter durum wheat varieties that were different in their ecological adaptability parameters. The first group included 11 highly responsive varieties recommended for cultivation on an intensive background, namely 'Alyy parus', 'Kontinent', 'Laguna', 'Kassiopeya', 'Akveduk' (Ukraine), 'Prikumskaya 142', 'Eyrena', 'Kiprida', 'Terra', 'Oniks', 'Kurant' (Russia). To obtain the largest average productivity there have been recommended to cultivate the following 11 varieties on the average agricultural background, namely 'Aksinit', 'Amazonka', 'Kermen', 'Uniya', 'Diona', 'Yakhont', 'Yubilyarka', 'Belgorodskaya yantarnaya' (Russia), 'Zolotoye runo', 'Gardemarin', 'Andromeda' (Ukraine), since these varieties were good adapted to various environmental conditions. The varieties 'Agat donskoy','Zolotko','Krupinka', 'Laska', 'Lazurit', 'Krucha', 'Stepnoy yantar' (Russia), 'Burshtin', 'Dnepryana', 'Perlina odesskaya' and 'Shulyndinka' (Ukraine) -to cultivate on a reduced agrofone, where they will give a fairly high yield from 8.45 to $9.67 \mathrm{t} / \mathrm{ha}$.
\end{abstract}

\section{Introduction}

Durum wheat Triticum durum Desf. is considered to be the second largest crop in the world after soft wheat. Its sown area is $14-17$ million ha, or $8 \%$ of soft wheat, and gross grain production is $30-35$ million tons. Durum wheat is the best raw material for pasta production, since high-quality pasta is produced from semolina (grains), and it is durum wheat that provides the highest yield of grains due to the large, solid glassy and dense endosperm $[1,2,3,4]$. The past decades have been characterized with significant changes and constant fluctuations of biotic and abiotic environmental factors, which made breeders

*Corresponding author: mts0304@mail.ru 
to pay constant attention to the issues of adaptability and stability of the quantitative traits of grain crops, first of all their productivity $[5,6,7]$.

One of the important requirements in the development of new varieties is to increase their resistance to environmental factors, which significantly affect the formation of potential productivity and grain quality. This effect is especially evident in the years with unfavorable conditions for cultivation, when the productivity greatly varies through the years. Therefore, at the last stage of the breeding process, special influence is paid not only to productivity improvement, but also to the study of ecological adaptability of varieties, i.e. a comprehensive assessment of the initial material according to adaptability and stability parameters, which makes it possible to identify promising genotypes by various characteristics [8]. It is they that are of the greatest value in agricultural production, since they are able to produce large and high-quality yields in various soil and climatic zones, weather and agricultural conditions $[9,10,11]$. Currently, the agricultural producers are interested in those varieties that tend to slightly decrease productivity and grain quality because of a rather unstable climate in the Rostov Region. Adaptability is considered as the ability of a genotype to maintain its characteristic phenotypic expression of a trait under certain environmental conditions, and stability is the ability of regulatory mechanisms to maintain a specific phenotype in different environmental conditions. The greatest adaptability of the genotype can be obtained due to the adaptability of some traits, which in turn determine the stability of the manifestation of others [12]. The intensive varieties with high genetic productivity potential should be cultivated in more favorable conditions. In difficult soil and climatic conditions, there should be grown varieties with a larger adaptive potential [13].

The climate in the Rostov region is sharply continental and is more subject to the influence of various unfavorable weather acts that have a negative effect on the grain crop development. These are droughts and dry winds, dust storms, frosts, especially early autumn and spring frosts during the periods of plant growing and development, soil ice covering, etc. The air temperature has a pronounced annual amplitude (in summer it's +37 $43{ }^{\circ} \mathrm{C}$, sometimes in winter it's $-20-30^{\circ} \mathrm{C}$ ) and it fluctuates during the day. Most of the region's territory is located in the arid zone, where the total annual rainfall varies from 290 to $580 \mathrm{~mm}$ in different parts of the region, most of which falls in winter and spring, less in autumn.

Thus, taking into consideration the unstable weather conditions of the Rostov region, the selection of the best varieties and the estimation of their environmental adaptability parameters should be of great importance, since the newly developed varieties should have an effective response to the changing environment. This is especially true for the south of the region, since winter durum wheat, due to its genetic characteristics, is especially responsive to stressful conditions in comparison with soft wheat.

\section{Materials and methods}

The current study was carried out in the years of 2017-2019. The objects of study were 34 varieties of winter durum wheat of domestic and foreign breeding. Domestic breeding was presented by 13 varieties 'Kristella', 'Agat donskoy', 'Aksinit', 'Amazonka', 'Kurant', 'Lazurit', 'Oniks', 'Diona', 'Eyrena', 'Kiprida', 'Yakhont', 'Yubilyarka', 'Terra' developed in the Federal State Budgetary Scientific Institution "Agricultural Research Center "Donskoy"; by 6 varieties 'Zolotko', 'Kermen', 'Krupinka', 'Laska', 'Uniya', 'Krucha' developed in the Federal State Budgetary Scientific Educational Institution "NTSZ named after P.P. Lukyanenko"; by 2 varieties 'Prikumskaya 142', 'Stepnoy yantar' developed in the Federal State Budgetary Institution "North Caucasian FNATs"; by the variety 'Belgorodskaya yantarnaya' developed in the FSBSI "Belgorodsky FNATs" and by 
12 varieties of foreign breeding (Ukraine). The variety 'Donchanka' was taken as a standard variety All the studied varieties were introduced into the State List of Breeding Achievements.

Seedbed preparation, sowing and cultivation were carried out in accordance with the recommendations Zonal farming systems of the Rostov region for 2013-2020. Sowing of the varieties with different ecology was carried out with the Wintersteiger Plotseed S seeder. There were three trial replications. The arrangement of plots was systematic. The accounting area was $10 \mathrm{~m} 2$. The varieties were laid in green-manured fallow. The seeding rate was 5 million germinating seeds per hectare. The harvesting was carried out with a Wintersteiger Classic combine. The soil of the experimental plot was ordinary heavy loamy blackearth (chernozem) with a thick (up to $140 \mathrm{~cm}$ ) humus layer with a low content of movable phosphorus $(20-25 \mu \mathrm{m} / \mathrm{kg})$ and with an increased content of exchangeable potassium $(350-400 \mu / \mathrm{kg}$ of soil).

The assessment of the environmental adaptability and stability indices was performed according to the S.A. Eberchart and W.A. Russel's method, edit. by V.A. Zykin. Mathematical and statistical data was processed according to B.A. Dospekhov methodology. Meteorological data of 2017-2019 was provided by the Zernograd weather station.

\section{Result and discussion}

Weather conditions during the years of study had contrasting indicators during the vegetation period of winter durum wheat, both in terms of precipitation amount (Fig. 1) and temperature (Fig. 2), which differed from average long-term data. The 2017 agricultural year in terms of precipitation amount $(576.4 \mathrm{~mm}$ with a norm of $583.5 \mathrm{~mm})$, their seasonal distribution, and temperature was not typical for our region (environmental index is -0.24), especially due to autumn drought when sowing was done after acceptable dates, namely 4-8 of October and the amount of precipitation in the 3rd decade of September and the first decade of October was $42.7 \mathrm{~mm}$ compared with $42.3 \mathrm{~mm}$ of average precipitation amount. The October was characterized by a shortage of precipitation (50\% of the norm) and a temperature fall on $1.5^{\circ} \mathrm{C}$, which hindered germination of sprouts. Autumn vegetation stopped in the third decade of November in the germination period (2-3 leaves), the plants had to spend the winter with a weak root system. During the winter period there were $107.4 \%$ of rainfall compared to the average long-term amount of precipitation. The average daily temperature was $-3.4^{\circ} \mathrm{C}$, which was lower on $0.8^{\circ} \mathrm{C}$ compared to the average longterm amount of precipitation. During the kernel ripening period (June) there were $88.6 \mathrm{~mm}$ of precipitation, which caused lodging of winter durum wheat in some places.

The maximum productivity was obtained from the domestic varieties developed by the Federal State Budgetary Scientific Institution "Agricultural Research Center "Donskoy", they are 'Agat Donskoy' and 'Lazurit' with 9.91 and 9.93 t/ha, respectively. The minimum productivity was obtained from the varieties 'Belgorodskaya yantarnaya' $(8.04 \mathrm{t} / \mathrm{ha})$ and 'Alyy parus' ( $8.12 \mathrm{t} / \mathrm{ha}$ ) developed by the Belgorod FNATs of RAS. The productivity of the standard variety 'Kristella' was 8.84 t/ha. 


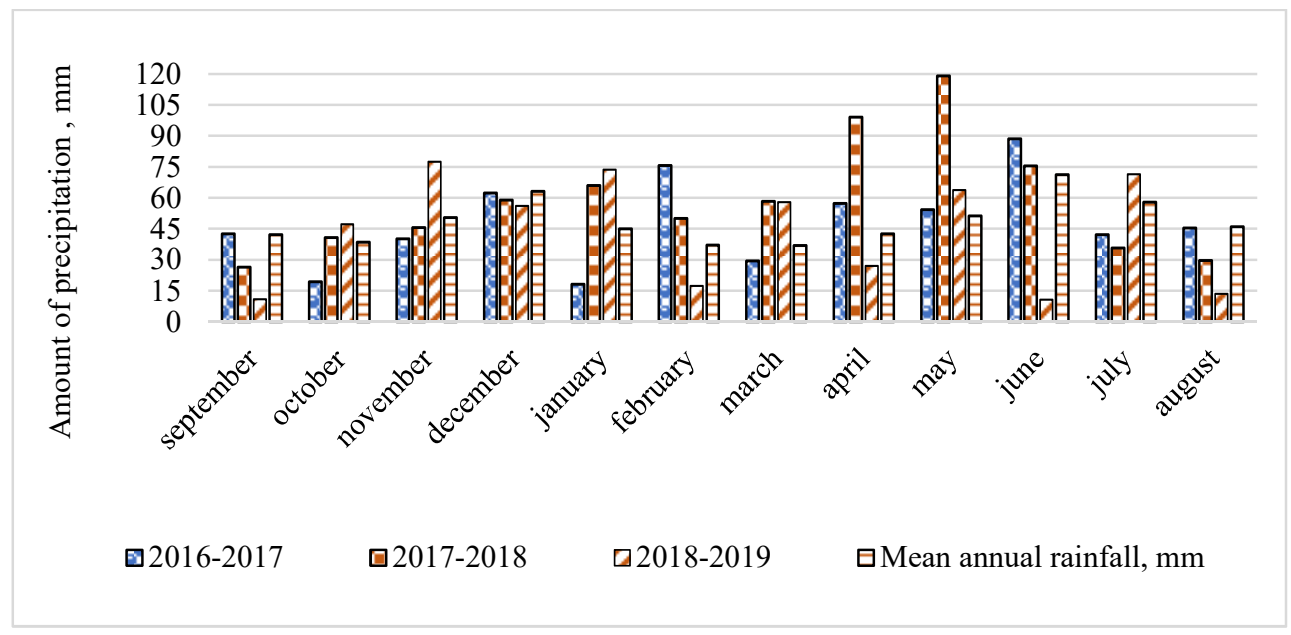

Fig. 1. Amount of precipitation over the years of study, mm (2017-2019).

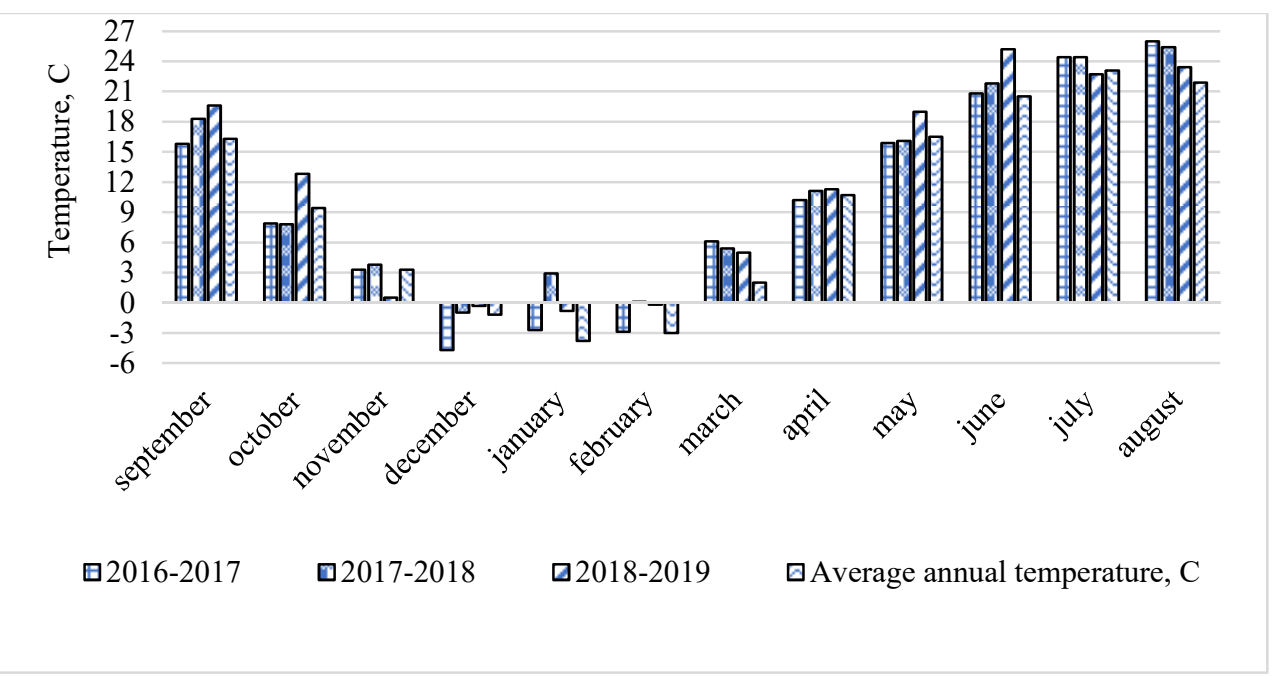

Fig. 2. Air temperature over the years of study, ${ }^{0} \mathrm{C}$ (2017-2019).

The 2018 agricultural year was unfavorable for winter durum wheat sowing in optimal terms, as the high temperature in August and September resulted in drying of the arable soil layer, there were $56.3 \mathrm{~mm}$ of precipitation, which were $63 \%$ of the precipitation norm. Sowing was done at the end of the optimal time (28-30 of September).

The precipitation at the end of October $(40.9 \mathrm{~mm}$ or $105 \%$ of the precipitation norm) and the higher temperature (on $3.4^{\circ} \mathrm{C}$ of the norm) contributed to the complete germination and tillering. During the winter period there were $175.1 \mathrm{~mm}$ of rainfall with a norm amount of $145.7 \mathrm{~mm}$.

The early start of spring vegetation at lower temperatures also contributed to further tillering of plants and development of a secondary root system with $276.5 \mathrm{~mm}$ of rainfall (211\% of the average long-term amount) and an average daily temperature of $10.8^{\circ} \mathrm{C}$ (with an average long-term temperature of $9.70^{\circ} \mathrm{C}$ ). This year due to the accumulated moisture reserves, durum winter wheat productivity was up to $14 \mathrm{t} / \mathrm{ha}$. The weather conditions index was 2.86 . The standard variety produced $11.53 \mathrm{t} / \mathrm{ha}$. 
The maximum yield of $13.01 \mathrm{t} / \mathrm{ha}, 13.03 \mathrm{t} / \mathrm{ha}$ and $13.26 \mathrm{t} / \mathrm{ha}$ was produced by the varieties of foreign selection 'Kontinent', 'Andromeda' and 'Akveduk' (Ukraine). The minimum yield of $11.11 \mathrm{t} / \mathrm{ha}$ and $11.17 \mathrm{t} / \mathrm{ha}$ was obtained from the varieties of domestic selection 'Belgorodskaya yantarnaya' (the Belgorod FNATs of RAS) and 'Krucha' ("RCG named after P.P. Lukyanenko").

The 2019 agricultural year turned to be extremely unfavorable for winter durum wheat for sowing time and germination, the index of weather conditions was -2.63 . The high temperatures in August $\left(+1.5^{\circ} \mathrm{C}\right.$ to the average long-term norm of $\left.21.9^{\circ} \mathrm{C}\right)$, in September $\left(+3.3^{\circ} \mathrm{C}\right.$ to the average long-term norm of $\left.16.3^{\circ} \mathrm{C}\right)$ with the absence of precipitation $(13.6$ $\mathrm{mm}$ in August, $10.9 \mathrm{~mm}$ in September) did not provide proper kernel filling, germination, sprouting.

Complete germination occurred on 1-3 of November, after $47.3 \mathrm{~mm}$ of precipitation in October. Winter durum wheat sowings had to spend winter in the sprouting phase (1-2 leaves). During the winter period there were $147.2 \mathrm{~mm}$ of precipitation. Frequent temperature fluctuations from positive to negative caused early plant germination, which led to the death of plants. The maximum yield of 7.46-7.55 t/ha was produced by the varieties 'Shulyndinka' and 'Andromeda' (Ukraine), the minimum yield of $5.31 \mathrm{t} / \mathrm{ha}$ was produced by the variety 'Oniks' (FSBSI ARC “Donskoy”, Russia).

The variance analysis showed that in 2017-2019 the factor A ('year') had a 95\% effect of the formation of productivity, the factor B ('variety') had a $2 \%$ effect and the factor 'year $\mathrm{x}$ variety' had a 3\% effect. Such a dominant influence of the factor A ('year') explained a significant productivity variation throughout the years under the effect of weather conditions (Fig. 3).

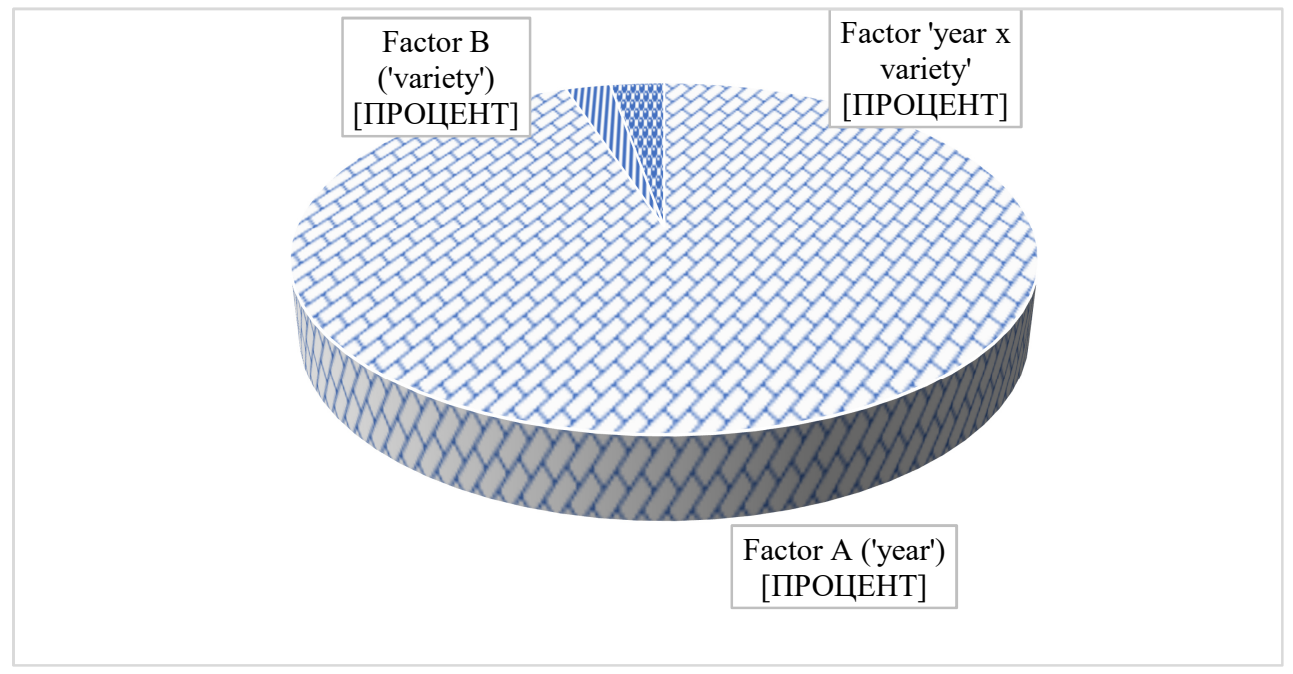

Fig. 3. A The proportion of factors in the formation of winter durum wheat productivity, \% (20172019).

One of the important indicators in the estimation of ecological adaptability of varieties is a linear regression coefficient bi, which shows their response to changes in weather and growing conditions. According to the model of Eberhart S.A., Russel W.A., the most valuable are those varieties for which bi> 1 , and $\sigma^{2} \mathrm{~d}$ (a stability coefficient) tends to zero.

Such varieties are responsive to the improved conditions, they are characterized by stable productivity and require a high level of agricultural technology. To determine the stability coefficient $\sigma^{2} \mathrm{~d}$ there were calculated theoretical productivity and deviations from the actual one. 
Based on this analysis there were identified 11 varieties with high responsiveness, namely 'Alyy parus' (bi = 1.07), 'Prikumskaya 142' (bi = 1.10), 'Eyrena' (bi = 1.10), 'Kiprida' (bi = 1, 12), 'Terra' (bi = 1.13), 'Laguna' (bi = 1.07), 'Kontinent' (bi = 1.12), 'Kassiopeya' (bi = 1.05), 'Oniks' (bi = 1.29), 'Akveduk' ( bi =1.20), 'Kurant' (bi = 1.20) (Table 1).

Table 1. Productivity of winter durum wheat varieties and parameters of ecological adaptability and stability (2017-2019).

\begin{tabular}{|c|c|c|c|c|c|c|c|c|c|c|}
\hline \multirow{2}{*}{ Variety } & \multicolumn{3}{|c|}{ Productivity. t/ha } & \multirow[t]{2}{*}{$\Sigma \mathbf{Y i}$} & \multirow{2}{*}{$\mathbf{Y i}$} & \multicolumn{3}{|c|}{$\begin{array}{c}\text { Theoretical } \\
\text { productivity. t/ha }\end{array}$} & \multirow{2}{*}{ bi } & \multirow[t]{2}{*}{$\mathbf{o}^{2} \mathrm{~d}$} \\
\hline & 2017 & 2018 & 2019 & & & 2017 & 2018 & 2019 & & \\
\hline $\mathrm{Kr}$ & 84 & 3 & 6.2 & 26 & 8.86 & 8.63 & 11. & 6.34 & 0.96 & 0.07 \\
\hline Agat donskoy & 9.91 & 11.81 & 6.83 & 28.55 & 9.52 & 9.31 & 12.07 & 7.18 & 0.89 & 0.55 \\
\hline Aksinit & 9.01 & 11.99 & 6.44 & 27.44 & 9.15 & 8.91 & 12.04 & 6.49 & 1.01 & 0.01 \\
\hline Alyy parus & 8.12 & 12.38 & 6.59 & 27.09 & 9.03 & 8.77 & 12.09 & 6.22 & 1.07 & 0.64 \\
\hline Amazonka & 9.61 & 11.29 & 5.85 & 26.75 & 8.92 & 8.69 & 11.69 & 6.37 & 0.97 & 1.28 \\
\hline Zolotko & 8.65 & 11.41 & 6.52 & 26.58 & 8.86 & 8.65 & 11.41 & 6.52 & 0.89 & 0.00 \\
\hline Kermen & 9.16 & 12.01 & 6.79 & 27.96 & 9.32 & 9.09 & 12.04 & 6.82 & 0.95 & 0.01 \\
\hline Krupinka & 8.32 & 11.9 & 6.81 & 27.03 & 9.01 & 8.78 & 11.70 & 6.54 & 0.94 & 0.32 \\
\hline Kurant & 8.20 & 12.20 & 5.63 & 26.03 & 8.68 & 8.39 & 12.11 & 5.52 & 1.20 & 0.06 \\
\hline Laska & 8.68 & 11.66 & 7.04 & 27.38 & 9.13 & 8.93 & 11.56 & 6.89 & 0.85 & 0.10 \\
\hline $\begin{array}{c}\text { Prikumskaya } \\
142\end{array}$ & 9.05 & 11.81 & 5.74 & 26.60 & 8.87 & 8.61 & 12.02 & 5.98 & 1.10 & 0.30 \\
\hline Uniya & 8.71 & 11.95 & 6.52 & 27.18 & 9.06 & 8.82 & 11.89 & 6.46 & 0.99 & 0.02 \\
\hline Lazurit & 9.93 & 12.09 & 6.99 & 29.01 & 9.67 & 9.45 & 12.30 & 7.25 & 0.92 & 0.34 \\
\hline Onik & 9 & 1 & 5. & 2 & 8.94 & 3 & 3 & 5 & 1.29 & 0.25 \\
\hline Diona & 8.83 & 11.61 & 6.36 & 26.80 & 8.93 & 8.70 & 11.65 & 6.43 & 0.95 & 0.02 \\
\hline Eyrena & 8.81 & 11.81 & 5.76 & 26.38 & 8.79 & 8.53 & 11.94 & 5.90 & 1.10 & 0.11 \\
\hline Kiprida & 9.27 & 12.33 & 6.12 & 27.72 & 9.24 & 8.97 & 12.44 & 6.29 & 1.12 & 0.13 \\
\hline Yakhont & 8.48 & 11.88 & 6.57 & 26.93 & 8.98 & 8.75 & 11.75 & 6.43 & 0.97 & 0.11 \\
\hline Yubilyarka & 9.26 & 12.42 & 7.11 & 28.79 & 9.60 & 9.37 & 12.37 & 7.05 & 0.97 & 0.02 \\
\hline Krucha & 8.13 & 11.17 & 6.06 & 25.36 & 8.45 & 8.23 & 11.11 & 6.00 & 0.93 & 0.02 \\
\hline Terra & 8.80 & 12.02 & 5.79 & 26.61 & 8.87 & 8.60 & 12.10 & 5.90 & 1.13 & 0.06 \\
\hline Stepnoy yantar & 8.41 & 11.22 & 6.18 & 25.81 & 8.60 & 8.38 & 11.23 & 6.18 & 0.92 & 0.00 \\
\hline $\begin{array}{c}\text { Belgrodskaya } \\
\text { yantarnaya }\end{array}$ & 8.04 & 11.11 & 5.59 & 24.74 & 8.25 & 8.01 & 11.11 & 5.62 & 1.00 & 0.00 \\
\hline Burshtin & 8.77 & 11.87 & 6.74 & 27.38 & 9.13 & 8.90 & 11.82 & 6.66 & 0.94 & 0.03 \\
\hline Dnepryana & 9.49 & 11.68 & 6.96 & 28.13 & 9.38 & 9.18 & 11.81 & 7.14 & 0.85 & 0.15 \\
\hline $\begin{array}{c}\text { Perlina } \\
\text { Odesskaya }\end{array}$ & 9.40 & 11.79 & 6.82 & 28.01 & 9.34 & 9.12 & 11.91 & 6.97 & 0.90 & 0.12 \\
\hline Laguna & 8.57 & 12.62 & 6.81 & 28.00 & 9.33 & 9.07 & 12.39 & 6.52 & 1.07 & 0.39 \\
\hline Kontinent & 8.19 & 13.01 & 7.01 & 28.21 & 9.40 & 9.13 & 12.60 & 6.45 & 1.12 & 1.37 \\
\hline Zolotoye runo & 9.38 & 11.49 & 5.86 & 26.73 & 8.91 & 8.67 & 11.80 & 6.25 & 1.01 & 0.75 \\
\hline
\end{tabular}




\begin{tabular}{|c|c|c|c|c|c|c|c|c|c|c|}
\hline Gardemarin & 8.66 & 12.01 & 6.74 & 27.41 & 9.14 & 8.91 & 11.91 & 6.59 & 0.97 & 0.10 \\
\hline Kassiopeya & 8.67 & 12.51 & 6.82 & 28.00 & 9.33 & 9.08 & 12.33 & 6.57 & 1.05 & 0.26 \\
\hline Akveduk & 8.74 & 13.26 & 6.77 & 28.77 & 9.59 & 9.30 & 13.02 & 6.43 & 1.20 & 0.49 \\
\hline Shulyndinka & 9.60 & 11.64 & 7.46 & 28.70 & 9.57 & 9.39 & 11.74 & 7.57 & 0.76 & 0.07 \\
\hline Andromeda & 8.91 & 13.03 & 7.55 & 29.49 & 9.83 & 9.59 & 12.72 & 7.17 & 1.01 & 0.70 \\
\hline$\Sigma \mathrm{Yj}$ & 301.6 & 406.9 & 220.3 & & & & & & & \\
\hline $\mathrm{Yj}$ & 8.87 & 11.97 & 6.48 & & 9.11 & & & & & \\
\hline $\mathrm{Ij}$ & -0.24 & 2.86 & -2.63 & & & & & & & \\
\hline $\mathrm{HCP}_{05}$ & 0.21 & 0.12 & 0.13 & & & & & & & \\
\hline
\end{tabular}

In addition, the varieties 'Kurant', 'Terra', 'Eyrena', and 'Kiprida' were stable genotypes (the stability coefficient was $\sigma^{2} \mathrm{~d}=0.05-0.13$ ); the stability coefficient of the other varieties varied from 0.25 to 0.64 . The varieties with high bi and $0^{2} \mathrm{~d}$ values were less valuable, as their high responsiveness was combined with low yield stability. The variety 'Kontinent' combined high responsiveness with instability of yields $\left(\sigma^{2} \mathrm{~d}=1.37\right)$.

There were identified 9 varieties with a bi index close to 1 , which varied from 0.95 to 1.01 , which indicated their adaptability, i.e. these varieties poorly responded to growing conditions, i.e. there were adaptive. Among adaptible varieties with a linear regression coefficient of 0.95-1.01 (bi), there could be distinguished the varieties 'Aksinit', 'Amazonka', 'Kermen', 'Uniya', 'Diona', 'Yakhont, 'Yubilyarka', Belgorodskaya yantarnaya', 'Zolotoye runo', 'Gardemarin', 'Andromeda'.

The stability coefficient $\sigma^{2} \mathrm{~d}$ of these varieties varied from $0.00-0.75$, which indicated their high genotype stability, and the productivity was $8.25-9.83 \mathrm{t} / \mathrm{ha}$. The standard variety 'Kristella' according to the obtained indicators was a stable and adaptible variety ( $\mathrm{bi}=0.96$, $\left.\sigma^{2} \mathrm{~d}=0.07\right)$.

The varieties 'Agat donskoy', 'Zolotko', 'Krupinka', 'Laska', 'Lazurit', 'Krucha', 'Stepnoy yantar', 'Burshtin', 'Dnepryana', 'Perlina odesskaya' and 'Shulyndinka' belonged to genotypes in which bi $<1$ and $0^{2} \mathrm{~d}$ was close to zero, i.e. they slightly responded to improvement of weather conditions and had fairly high productivity from 8.45 to $9.67 \mathrm{t} / \mathrm{ha}$, which indicated high adaptability and stability of these varieties. The bi regression coefficient was $0.76-0.94$, the stability indices $0^{2} \mathrm{~d}$ ranged from 0.00 to 0.34 . The varieties of this group have been recommended to cultivate on a lower agricultural background.

\section{Conclusions}

The set of studied varieties was diverse in terms of environmental adaptability. Their assessment allows distributing them according to the level of adaptability to growing conditions. There were identified 11 varieties with high responsiveness, 10 of which with stable yields, which have been recommended to be cultivated on an intensive agricultural background. The variety 'Kontinent' is a highly responsive variety with instability of its genotype. The varieties 'Agat donskoy', 'Zolotko', 'Krupinka', 'Laska', 'Lazurit', 'Krucha', 'Stepnoy yantar', 'Burshtin', 'Dnepryana', 'Perlina odesskaya' and 'Shulyndinka' are better to cultivate on a lower agricultural background, where they produce maximum yileds at minimum costs, since their liner regression coefficient is bi $<1$, and the set of varieties is characterized with high productivity $(8.45-9.67 \mathrm{t} / \mathrm{ha})$. The varieties 'Kristella', 'Aksinit', 'Amazonka', 'Kermen', 'Uniya', 'Diona', 'Yakhont', 'Yubilyarka', 'Belgorodskaya yantarnaya', 'Zolotoye runo', 'Gardemarin', 'Andromeda' show a great correlation between their productivity change and the change in the growing 
conditions, i.e. these varieties are well adapted to various weather conditions and they are recommended to cultivate on an average agricultural background to obtain the largest average productivity.

\section{References}

1. T. Sertac, Proceedings of the International Symposium on Genetics and breeding of durum wheat Series A: Mediterranean Seminars 110, 589-593 (2014)

2. USDA Foreign Agricultural Service. Grain and Feed Annual, GAIN Report No: TR5016 (Agricultural Service, Ankara, 2015)

3. O. Le Lamer, X. Rousselin, The durum wheat market. In Studies of FranceAgriMer (Montreuil-sous-Bois CEDEX, France, 2011)

4. E.S. de Vasconcelos, M.S. Reis, C.D. Cruz, T. Sediyama, C.A. Scapim, Acta Scientiarum Agronomy 33, 251-257

(2011) http://dx.doi.org/10.4025/actasciagron.v33i2.8272

5. M.C. Marques, O.T. Hamawaki, T. Sediyama, M.R. Bueno, M.S. Reis, C.D. Cruz, A.P.O. Nogueira, Bioscience Journal 27, 59-69 (2011)

6. S. El-Areed, M.M. Nachit, A. Hagaras, S. El-Sherif, M. Hamouda, Proceedings of the International Symposium on Genetics and Breeding of Durum Wheat (CIHEAM, Bari, 2014)

7. A.P. Bonjean, W.J. Angus, M. van Ginkel, The World Wheat Book: A History of Wheat Breeding (Lavoisier, Paris, 2016)

8. A.P. Samofalov, S.V. Podgornyy, Agrarian Bulletin of the Urals 5(123), 13-16 (2014) https://elibrary.ru/item.asp?id=21685179

9. I.G. Grebennikova, A.F. Aleynikov, P.I. Stepochkin, Bulgarian J. Agricultural Science 17(6), 755-759 (2011)

10. A.P. Bilityuk, L.A. Garbar, S.M. Tsyganchuk, Bulletin of the Poltava state agrarian Academy (scientific and production professional magazine 3, 68-71 (2012)

11. D.I. Chanyshev, A.F. Aleynikov, I.G. Grebennikova, Siberian Bulletin of agricultural science 3, 129-131 (2012)

12. N. Kefelegn, Genotype x environment interaction of released common bean (Phaseolus vulgaris l.) varieties, in eastern Amhara region (School of Graduate Studies of Haramaya University, Ethiopia, 2012)

13. J.L. Araus, J.E. Cairns, Trends Plant Sci. 19, 52-61 (2014) doi: 10.1016/j.tplants.2013.09.008 